\title{
The Discourse of Cyber Literature in Indonesia
}

\author{
Fitri Merawati and Iis Suwartini \\ Indonesian Language and Literary Education, Faculty of Teacher Training and Education, \\ University of Ahmad Dahlan, Indonesia \\ fitri merawati@yahoo.co.id
}

\begin{abstract}
This research describes the discourse of cyber literature in Indonesian using the theories of Michel Foucault's discourse. This research is describes research. The subjects is cyber literature. Data is collected by engineering literature and observation. The analysis process is performed by applying the method of excavation. The analisyst showes that cyber in the arguments for and against cyber literature found in the various discourses on the subject, a continuity and discontinuity related to cyber literature in Indonesia is evident. Continuity is evident in the position of the authors, who have the same rights as creators whether they be amateurs or professionals; the definition of cyber literature and genres of cyber literature; and the position of readers, who have the opportunity to communicate and be immediately involved with writers and works of cyber literature. Discontinuity is evidenced in the Indonesian literary culture's rejection of the canonicity of cyber literature, which has limited the growth of cyber literature as a literary form in Indonesia.
\end{abstract}

Keywords: Foucault, cyber literature, Indonesia

\section{INTRODUCTION}

Significant developments in information and communications technology, an increased in varieties of collectivity, and an increase technological orientation of culture and civilization have a positive correlation [1]. This is in line with Saut Situmorang's statement that the emergence of cyber literature cannot be viewed independently of the introduction of advanced internet technology in the world of communications [2]. Cyber literature in Indonesia began to emerge towards the end of the 1990s, and by May 2001 an anthology of cyber poetry, titled Graffiti Gratitude, was published; it included works of the Yayasan Multimedia Sastra, including poets such as Iwan Soekri Munaf, Nanang Suryadi, Cunong Nunuk Suraja, Tulus Widjarnako, and Medy Loekito. Arguments for and against cyber literature then promoted interesting discourses on the medium, which became increasingly heated after Ahmadun Yosi Herfanda, the editor of Republika, described cyber literature as a "wastebin" in his 2001 article "Cyber Poetry: Genre or Wastebin". He made this statement because he considered works of cyber literature to be of such poor quality that they would never be accepted or published by the print media.

Despite the various opinions on cyber literature - both positive and negative - which have been made, it cannot be denied that the medium has opened up new spaces for the development of an alternative literature which "rebels" against the establishment and the prevalent aesthetics; cyber literature does not merely duplicate print literature. Cyber media has become a place for people with freedom of creativity (however wild) and a passion for writing, those who have 
been recognized by the print media, be it in literary columns, magazines, or anthologies. Cyber literature offers the same opportunities to all writers, be they professionals or amateurs.

As such, the discourse of cyber literature, which includes discussion of the origins of cyber literature and its developments in Indonesia, as well as the continuity and discontinuity found in the medium, is important to research, particularly seeing the synergy of the various discourses, powers, and knowledge in cyber literature.

Based on the above discussion, this paper will examine the discourse of cyber literature, with particular focus on the origin and emergence of cyber literature, the development of cyber literature in Indonesia, and the continuity and discontinuity of cyber literature in Indonesia.

\section{THEORETICAL BACKGROUND}

Foucault refuses all forms of "exhaustive" theories, continuing instead Nietzsche's idea of "genealogy": originating in the present, one looks to the past until a localized difference is found, a difference which is then retraced to the present through its continuities and discontinuities. GDA attempts to develop and maintain singularities of events, ignoring the spectacular for the discredited, focusing on the range of phenomena which have been denied by a certain history. Discourse analysist focuses on local knowledge, unsustainability, disqualification, and nonvalidity, in order to challenge the claims of integrated theories which instead filter, hierarchize, and rearrange knowledge in the name of "the truth"; as such, discourse analysist is a form of criticism [3].

According to Foucault, in order to obtain the genealogy of an object, several things are required: involvement, knowledge, and power. All of these are interrelated. Discourses arise together with power and knowledge; the reverse also holds true. Discourses are a collection of speech acts which hold meaning and judgment, though not always at the conscious level (as in ideology) [4]. In reality, the discourses found in a society will be highly variable. They are, he writes, hiding still other discourses; this leads to the terms dominant discourse and oppressed discourse.

Foucault also deals with the concept of power. Haryatmoko [5] argues that Foucault finds power everywhere: power is the direct effect of separation, difference, and inequality (discrimination). Power uses a variety of techniques and strategies to maintain itself, one of which being the continuation of inequality through the preservation of discrimination or differentiation. Power sustains mobility, while at the same time freezing it [4]. All powers are compiled, settled, and manifested through a certain knowledge and discourse. A certain discourse will produce a certain truth, a certain knowledge, which then gives rise to power and its effect. Foucault argues that this "truth" is actually produced, because each power must generate and produce its own truth. The power then herds its followers towards belief in this established "truth". Power always has the pretensions to form a new regime of truth, which is then disseminated through discourse which is further produced and shaped by power. Although it may seem to be given and natural, in reality it is but 'a group of sociocultural constructs regarding power and dominance".

Aside from discourse, power, and knowledge, all of which are in synergy, in GDA there are also continuities and discontinuities. Foucault argues that each historical period has a system of thought which determines how knowledge can be applied in that period. Each era has and defines its own discourse, and these definitions may change radically from period to period; such changes result in a fracturing of the episteme and discontinuity. For Foucault, history is not of the past, but of the present. Foucault states that historical study must always be, in some way, tied to the present. This, he says, is clearly because the present day is full of issues which 
can be addressed by understanding certain aspects of the past; thus, history is written not for the past, but for the present. Continuity occurs when events of the past are considered to have continued to the present. In his book The Order of Things: An Archaeology of the Human Sciences, Foucault states that in history there will always be the possibilities of anomalies and divergences which are ignored by historians. These divergences and anomalies are what he terms discontinuities.

\section{METHOD}

This collection of data for this project was completed through secondary research and observation. The secondary research involved reading papers, articles, and books related to cyber literature, as well as the polemics regarding the emergence of the medium. Observation was completed through participation in a number of events related to cyber literature, including discussions and seminars. The analysis for this research was completed using the excavation method, namely a controlled activity related to field research which involved observation, recording, and interpretation of artifacts. The goal of such research is to observe and check various elements of the research object, as well as to greater understand it and connect it with earlier records regarding the aforementioned artifacts, and also to conduct analysis, interpret the results, and disseminate it.

\section{RESULT AND DISCUSSION}

According to the Oxford English Dictionary, the concept of a mass media was first recognized in the 1920 s, and the term "communications revolution" arose only in the 1950s. This does not mean, however, that there are no older mediums of communication. Even in Greek and Roman times, rhetoric (the study of oral and written communications) was studied [6]. The term cyber literature is derived from the terms electronic literature and digital literature. The history of cyber literature cannot be taken separately from that of hypertext, which is the fundamental force of cyberspace. Hypertext allows users to explore cyberspace, from window to window, display to display, thousands of pages linked to each other, without a clear beginning or end, all having textual elements which link to others. The term hypertext was introduced by Ted Nelson in 1965 to describe the interconnectivity of an unlimited number of literary texts. In his book Literary Machine, Ted Nelson wrote that:

"literature is an ongoing system of interconnecting documents...in any ongoing literature there is perpetual interpretation and reinterpretation and links between documents help us follow the connections"[7]

Piret Viires, in her essay "Literature in Cyberspace", states that the most comprehensive definition of cyber literature originates from the concept of digital literature, namely literature which is made and presented via the computer; this is predominantly through the internet, but may also be through CDs or computer hard drives. Narrowly defined, the concept of cyber literature can be characterized thusly: multi-linear; nodes (a block of text connected with various hypertext links) connected through links; connections of written text to multimedia, and interactivity. Viires statement regarding cyber literature is similar to that presented by Katherine Hayles [8]: cyber literature is "... generally considered to exclude print literature that has been digitized, is by contrast 'digital born,' and (usually) meant to be read on a computer." A similar definition is also presented by the Electronic Literature Organization (ELO): "[cyber literature 
is] work with an important literary aspect that takes advantage of the capabilities and contexts provided by the stand-alone or networked computer."

Electronic literature, which developed together with personal computers at the end of the 1980s, was originally a form of fiction which used hypertext and hyperlinks to connect the story's elements. The first work of electronic literature is considered to be Afternoon, a story (1987) by Michael Joyce, which was followed by Stuart Moulthrop's Victory Garden (1992) and Shelley Jacson's Patchwork Girl (1995) [8]. Academic discourse on cyber literature had already begun by the end of the 1980s. The first conference on the subject was held in 1987, and it continues to this day. A major figure in the study of electronic literature is George P. Landow, who has published two monumental books on hypertext literature: The Convergence of Contemporary Critical Theory and Technology (1992) and Hypertext 2.0: The Convergence of Contemporary Critical Theory and Technology (1997) [8].

According to Landow, technology has paved the way for new discourse in the literary world. From his books, it becomes clear that cyber literature is a blending of "literature" and "media". Literature is the most basic requirement and ingredient in cyber literature. Another researcher, Katherine Hayles, states in her book My Mother Was a Computer (2005) that the media serves as a "mother" to cyber literature, whereas literature itself is the "father". As such, cyber literature contains traits inherited from both of its "parents", namely traits from literature and traits from the media; literary traits include creativity, because it is a way for the authors to express themselves. The origins of cyber literature, then, have led to various definitions of the medium, which in turn show how various forces have attempted to "discipline" cyber literature.

Aside from this "disciplining" in the form of definitions, there is also the disciplining of writers and readers of cyber literature. In recent times, two traditions of writing have been dominant, namely print and electronic. Print literature and electronic literature can be differentiated by how they present a text, or through what Hayes describes as their "code". This difference in code is what separates the two traditions; print literature has a code of literacy, whereas electronic literature has a code of electracy [8]. If this is investigated, it becomes evident that writers and readers are both in the position to synergize. Writers and readers form a partnership through which they can help each other develop. Commentary and criticism can be directly conveyed to writers, allowing them to improve the works in progress. Writers, on the other hand, surrender the act of reading entirely to their readers. Readers can directly influence writers, though the writers retain the right to determine how they form and present their own creativity.

Disciplining is also evident in the genres of cyber literature. Genres of cyber literature, based on the understanding of electronic literature as discussed by the Electronic Literature Organization (in Hayles, 2008:15) are: (1) hypertext fiction; (2) interactive fiction; (3) hypertext poetry; (4) interactive poetry; (5) animated poetry; (6) email- or blog-based fiction; (7) computer installed literature; (8) computer generated fiction; (9) computer generated Poetry; (10) collaborative fiction; and (11) online fiction. In understanding these different genres of cyber fiction, then we must look to the origin of the term cyber, which in turn depends on an understanding of cyberspace and the term's origins. The term cyberspace was first introduced by a science fiction writer, William Gibson, in his novel Burning Chrome (1982) before being popularized by his next novel, Neuromancer (1984). He explained that cyberspace was a hallucinatory agreement manifested and experienced every day by billions of operators considered worthy, from all nations, including students studying mathematics; cyberspace is a graphic representation of the abstracted data from computer storage which can be found in 
human systems. The term then influenced the creation of terms such as cyber literature, which was originally known as electronic literature and digital literature.

The emergence of these genres of cyber literature then ignited discussion over the canonization of cyber literature, a discourse which has followed in the traces of the existing literary canons. Scott Rettberg, in his essay "An Emerging Canon? A Preliminary Analysis of All References to Creative Works in Critical Writing Documented in the ELMCIP Electronic Literature Knowledge Base", quotes a statement by Astrid Ensslin that canon must "consist of texts which are considered culturally valuable by certain groups or societies, and as such 'worth' passing down to future generations". He also emphasizes that canon has psychological and sociological effects on groups familiar with the work(s) in question. He explains that canonization is a dynamic process, and that in a diverse society the multitude of chosen canons have a detrimental effect on the canon which should be affected. Ensslin states that, in determining the canonicity of works of cyber literature, one must look at production aspects (innovativeness), objective aspects (depth of themes), formal aspects (overstructuring esthetic and semiotic interactions) and aspects of reception (criticism, anthologization, degree of canonization and motivation, and effect on readers).

Regarding cyber literature in Indonesia [9] explains that cyber literature has become an important medium and discourse because of its flexibility and ability to become a "barometer" of sorts for the future developments in Indonesian literature. Cyber literature in Indonesia emerged at the end of the 1990s, and was popularized in 2001 after a cyber-literature website launched the anthology Graffiti Gratitude on 9 May 2001, with works by Sutan Iwan Soekri Munaf, Nanang Suryadi, Cunong Nunuk Suraja, Tulus Widjarnako, and Medy Loekito; all of these writers were members of the Yayasan Multimedia Sastra. Support for, but also criticism of, this new medium soon developed. TS Pinang, for instance, stated that the forces of censorship found in the print media could not exist on the internet. He explored other issues as well:

Jadi tidak perlu adanya cyberphobia dan tidak perlu dicemaskan jika sastrawan cyber mencetak buku, atau mengirimkan karya tulis mereka ke media cetak maupun elektronik. Toh, ketika mereka "berintegrasi" dengan media konvensional itu, mereka tetap mengikuti aturan main dan patuh pada otoritas "rezim sastra" yang berkuasa di sana. Lantas, apakah sastrawan cyber melakukan "pengkhianatan" ketika memasuki wilayah sastra cetak? Lantas apakah sastrawan cyber lantas menjadi sosok makhluk asing ketika ia berkunjung ke dunia luar dunia cyber? [10]

(“... there is no need for cyberphobia, and no need to worry if cyber-authors publish their own books, or submit their works to print or electronic media. The problem is, once they "integrate" with conventional media such as these, then they follow the rules and subjugate to the authority of the "literary regime" in power. Then, is a cyber-author committing "treason" by submitting works to the print media? And will the cyberauthor be treated as a foreigner once he steps into the print world?)

Literature (both cyber and print) should develop in tandem, not be claimed to be better than the other, so that literature can be more useful for society. Furthermore, there is Usman KJ Suharjo's statement that cyber literature is a continuation of orality and oral literature, which indicates the close connection between the two. The philosophy of cyber literature is no different than that of oral literature, written literature, print literature, and other forms of literature, because it is also intended to intellectually stimulate society's cultural sphere. Literature 
functions to smooth humanity's rough edges, and it is here that the significance of literature becomes increasingly relevant in dealing with modern issues - no matter the medium [11].

Statements made in Indonesia regarding the canonicity of cyber literature do not follow the position of the ELO. A work is not determined to be canon or non-canon based on the text per se, but rather elements outside of the work; it is influenced by the interests of individuals and groups and how said interests relate to the status of a work as canon or not. Saut even declares the issue of canonicity to be a political one, and as such states that there is no need for a "cyber-literary canon" in Indonesia. Literature, he writes, is freedom of thought and expression, and as such should not be vested with political interests.

Based on the above discussion, it is clear that there is continuity and discontinuity present in cyber literature as it has developed in Indonesia. Continuity can be found in aspects related to the writers, in aspects related to the works themselves (in terms of definition and genre), and in aspects related to the readers. However, cyber literature in Indonesia also exhibits a discontinuity in the determination of its value, which has elsewhere led to the creation of a cyber-literary canon.

\section{CONCLUSION}

Technology is part of life. It offers quick and almost limitless service, as on the internet. The internet is a result of an American project, namely the ARPANET (Advanced Research Project Agency Network) and experiments by academics in 1969. This served as the embryo for cyber literature, which is now becoming increasingly common. Cyber literature is descended from electronic literature, and its development has caused polemics. These polemics have, in turn, positioned cyber literature as an object worth of research, including in regards to its genealogy. By tracing cyber literature from the earliest origins of the form, namely electronic literature, and then following its development in Indonesia, it becomes clear that much of the cyber literature created in Indonesia is similar to that which first came out of America. Cyber literature in Indonesia has undergone continuity in regards to the discourse related to the position of the authors, the discourse related to cyber literature (particularly its definition and genres), and the discourse related to the readers of cyber literature. Discontinuity is found in discourse over the canonicity of cyber literature. As such, it is clear that cyber literature in Indonesia has the right and obligation to determine its own fate through either rejection or acceptance of the previous experiences and statements which have occurred since cyber literature first emerged.

It is recognized that this initial research into the issue of cyber literature still has many shortcomings and limits. However, it is hoped that this paper can ignite further investigation into this medium, allowing for a more variative and in-depth understanding of the subject and related issues.

\section{REFERENCES}

[1] Faruk, "Sastra Cyber: Penjelajahan Awal terhadap Sastra di Internet," in Cyber Grafitti: Polemik Sastra Cyberpunk, S. Situmorang, Ed. Yogyakarta: Penerbit Jendela, 2004.

[2] S. Situmorang, "Sastrawan Cyber Mendobrak Hegemoni," in yber Grafitti: Polemik Sastra Cyberpunk, S. Situmorang, Ed. Yogyakarta: Penerbit Jendela, 2004.

[3] Faruk, "Tubuh, Kebudayaan dan Seksualitas," in Seks, Teks, Konteks. Tubuh Seksualitas dalam Wacana Lokal dan Global, T. Hanafi, Ed. Sumedang: Jurusan Sastra 
Inggris, Fakultas Sastra, Universitas Padjajaran and Kelompok Belajar Nalar, 2004.

[4] M. Foucault, La Volonte de Savoir, Ingin Tahu Sejarah Seksualitas. Jakarta: YOI, 2008.

[5] Haryatmoko, "Kekuasaan Melahirkan Anti-Kekuasaan: Menelanjangi Mekanisme dan Teknik Kekuasaan Bersama Foucault,” BASIS, vol. 1, no. 2, 2002.

[6] A. Brigs and P. Burke, Sejarah Sosial Media. Jakarta: Yayasan Obor, 2006.

[7] M. Rama, "Sastra Elektronik: Perkembangan Sastra di Era Teknologi Informasi," maderama99. [Online]. Available: http://maderama99.blogspot.com/2011/12/sastraelektronik.html. [Accessed: 13-Oct-2013].

[8] N. K. Hayles, Electronic Literature: New Horizon for The Literary. Notre Dame: University of Notre Dame Press, 2008.

[9] T. Aghata, "Sastra Cyber: Beberapa Catatan," in Sastra Pembebasan Antologi PuisiCerpen-Esai, H. Latief, Ed. Jakarta: Yayasan Damar Warga, 2004.

[10] T. Pinang, "Sastra Cyber Sastra (Bukan) Main-Main," in Cyber Grafitti: Polemik Sastra Cyberpunk, S. Situmorang, Ed. Yogyakarta: Penerbit Jendela, 2004.

[11] M. Al-Fayyadl, "Sastra Cyber: Relativisme Budaya Massal dalam Sastra Kita," in Cyber Grafitti: Polemik Sastra Cyberpunk, S. Situmorang, Ed. Yogyakarta: Penerbit Jendela, 2004. 